\title{
THE DYNAMICS OF THE FORM OF NUSANTARA MOSQUE: ARCHITECTURAL HOMOGENEITY VIS A VIS ARCHITECTURAL HYBRIDITY
}

Pudji Pratitis Wismantara

\author{
Department of Architecture, Faculty of Science and \\ Technology, State Islamic University Maulana Malik \\ Ibrahim of Malang, Indonesia \\ e-mail: vismantara@yahoo.co.id
}

\begin{abstract}
There are two points of departure in the design of mosque architecture in Nusantara, namely architectural homogeneity and architectural hybridity. Each provides the legitimacy of the architecture of identity formation. This paper seeks to explore the comparative, the concept of homogeneity and hybridity architecture, with a critical theory approach. The results of this search is, the concept of architectural homogeneity establishing assumption that certain architectural forms are supposed to represent "universal identity and modernity" of Muslim architecture. Meanwhile, the concept of architectural hybridity to show enrichment architecture identity because of the attempt to combine aspects of the universality of Islam with locality of Nusantara. Both these aspects can be positioned as the two subjects of mutual dialogue in a parallel position. As architecture strategy, the concept of hybridity reflects the effort or ijtihad in interpreting local and universal contextuality in the contemporary conditions that are constantly evolving and open.
\end{abstract}

Keywords: Nusantara mosque, hybridity of architecture, homogeneity of architecture, architecture strategy

\begin{abstract}
Abstrak
Ada dua titik tolak dalam desain arsitektur masjid di Nusantara, yaitu arsitektur homogenitas dan arsitektur hibriditas. Masing-masing memberikan legitimasi arsitektur dalam pembentukan identitas. Tulisan ini dimaksudkan untuk mengeksplorasi, perbandingan konsep arsitektur homogenitas dan hibriditas, dengan pendekatan teori kritis. Hasil dari pencarian ini adalah konsep homogenitas arsitektur yang membangun asumsi bahwa bentuk-bentuk arsitektur tertentu dianggap mewakili "identitas universal dan modernitas" arsitektur Muslim. Sementara itu, konsep hibriditas arsitektur untuk menunjukkan identitas arsitektur pengayaan karena usaha untuk menggabungkan aspek universalitas Islam dengan wilayah Nusantara. Kedua aspek ini dapat diposisikan sebagai dua subyek saling dialog dalam posisi paralel. Sebagai strategi arsitektur, konsep hibriditas mencerminkan upaya atau ijtihad dalam menafsirkan kontekstualitas lokal dan universal dalam kondisi kontemporer yang senantiasa berkembang dan terbuka
\end{abstract}

Kata kunci: Masjid Nusantara, arsitektur homogenitas, arsitektur hibriditas, strategi arsitektur

\section{Introduction: Three Trends of The Mosque's Images in Nusantara}

According to Hasan ud-Din Khan, until now there are three main trends of the mosque's image in Nusantara of mutual contestation for space. The first is a form of "Javanese Vernacular" showing features or pyramidal roof composite tajug (Figure 1) the second, the form of "Indo-Arabic Cross Cultural Mix" is dominated by forms of a dome, a bow and an additional tower (Figure 2), and the third is the modern form that takes rational geometric forms of inspiration ${ }^{1}$ (Figure 3 ). The third theme of this form seems to have dominated the discourse on contemporary mosque architecture in Nusantara. This trend raises the dynamic tension between use of certain forms of "newcomers" and resistance "local" with a number of interpretations and effort combinations. Tension also arose between the continuity of tradition and change towards modernity. In the context of relationships the local (Nusantara) with the newcomers ("Muslim" and Modern), occurs through the dynamics of the mosque rich architectural exploration, heading toward balance and a new identity.

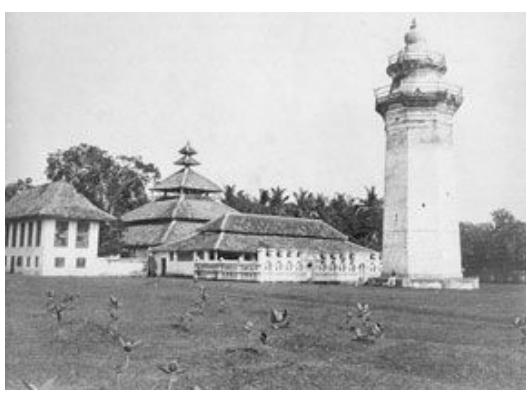

Figure 1. Vernacular Javanese (Source: Sumalyo, 2000) 


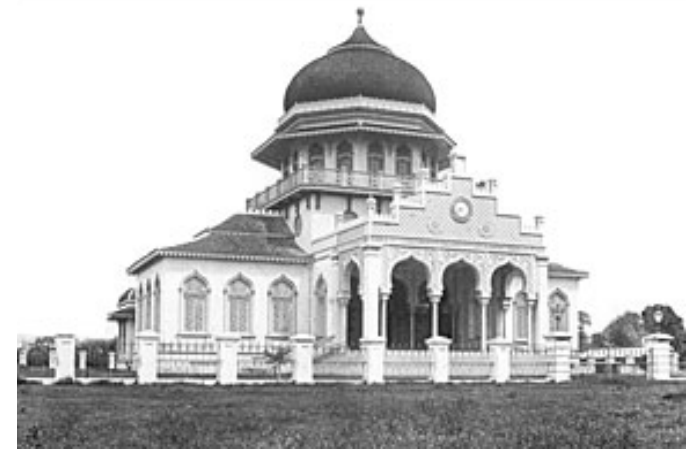

Figure 2. Indo-Arabic Cross Cultural Mix (Source: Sumalyo, 2000)

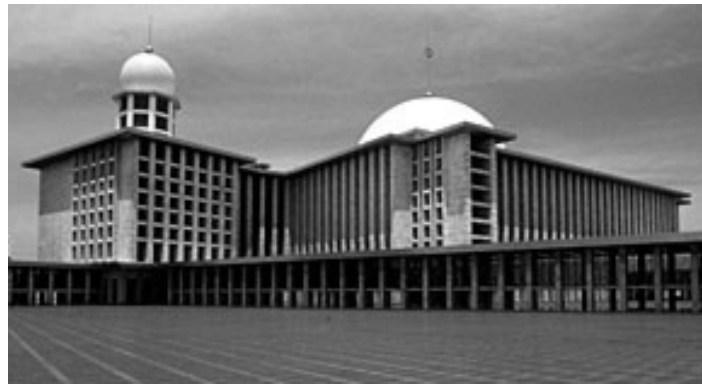

Figure 3. Modern Geometric

(Source: Sumalyo, 2000)

Departure from the above, at least two types of mosque architecture design in Nusantara. First, the mosque which uses only the local or the newcomers elements on the display its architectural form, which is homogeneous. Second, the mosque that integrate local elements with the newcomers in the architectural form of the display, so that is a hybrid. In other words, there are two point of departure in the design of the mosque in the archipelago, namely architectural homogeneity and architectural hybridity. Each provides the legitimacy of the architecture of identity formation.

This paper seeks to explore the comparative, the concept of architectural homogeneity and hybridity in mosque design, using a critical theory approach. The expected goals are, describes the concept of architectural homogeneity and hybridity critically and see the contribution of its use in architecture strategy. Critical theory approach is the perspective of reality by revealing "the real structure" behind the material reality critically ${ }^{2}$. Terms of ontological, this approach proposed method of dialogue to discover the ultimate truth of reality. In epistemological perspective adopted by the subject thought the author to intervene in determining the truth about something. In axiological, this approach aims to form a new consciousness to construct a mosque architecture in the present and future.
The identity of the Local Mosque Architecture in Nusantara

In oral and written tradition -since the influence of Islam in Nusantara plant- Demak Mosque is considered the first mosque in the Nusantara built by the wali's (Figure 4). Shape refers to the local tradition of non-Muslims who have been there before (Meru) in the form of a pyramid roof supported composite four pillar of his and also the porch. So that the mosque is not wrong if it can be a point of departure that inspired the development of Nusantara mosque architecture in the next. With reference to local, this mosque is not a monument to the Islamic identity "universal" to the local Muslim community.
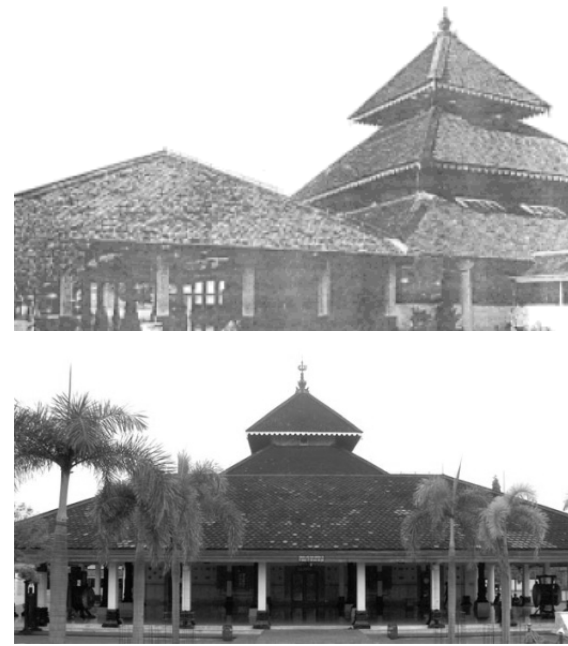

Figure 4. Demak Mosque has a form which refers to the local tradition of Islamic pre-existing (Meru). The mosque is a prototype development of mosque architecture in the archipelago in the next period. (Source: Indonesian Heritage, 2000)

In subsequent historical developments, the rise of a number of mosques "Demakan" (Javanese Vernacular) type troughout Nusantara. Mosque with this type generally have a form that takes the basic reference Demak Mosque as a continuity factor which has undergone a transformation as a factor of change. Singkarak Mosque in West Sumatra is an example that takes continuity piled pyramidal roof with the transformation of the roof ribs bending stacks (Figure 5). Bending ribs actually more as a form of adaptation to the home architecture archway usual, so that harmony can be achieved environment. In other developments also occurred moments where the elements of the newcomers combined or combined with the local elements without the need to eliminate or ignore one of the elements. Great Mosque of Jogjakarta, for example, combining the local elements (Tajug of Java) with external elements (form, which refers to European classical architecture) (Figure 6). European classical 
elements found on the crest of the roof attached to the roof of the porch, pediment form refers more neo-classical architecture of Europe. Another element is the ornamentation and decoration of the Neo-classical mixed with unique ornaments and decorations that are either Java or just patch together. Local resistance shown by not using the elements of the "outside" of immigrants as the main part of the building. These elements in most cases are treated as additional elements "attached" to the main elements of the local as a fixed element to dominate the display.

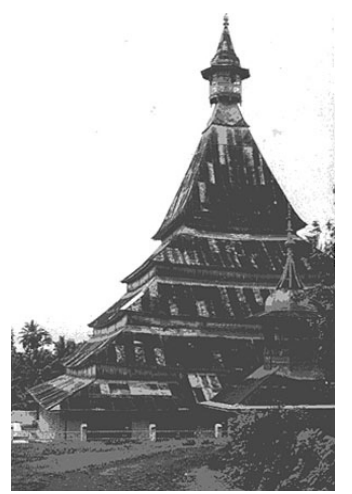

Figure 5. The variants Demakan type: Singkarak Mosque in West Sumatra (Source: Indonesian Heritage, 2000)

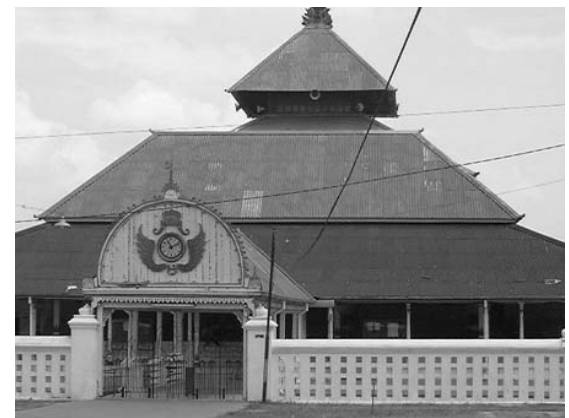

Figure 6. The variants Demakan type and Jogjakarta Great Mosque (Source: Indonesian Heritage, 2000)

\section{Mosque Architecture Homogeneity I: The image of Pan-Islamism}

Striking phenomenon that emerged in the early twentieth century mosque architecture is the tendency to realize the efforts in the homogenization value of architectural expression. Elements such as a bow shape, domes, and towers being set up in mosques scattered around the Nusantara. In the design of the mosque, it was thought that certain architectural forms can be considered to represent "universal identity" of Islamic architecture. At least there are two factors behind this phenomenon. First, is the emergence and the spread of the spirit of PanIslamism in all parts of the world that proclaimed religious Wahabiyah Islamic streams with purification and modernization. Religious streams longed recovery "glory" to understand Islam through a unified search of Islam on all aspects of life $e^{3}$. The need for unification of views is finally showing itself in the tendency to formalize and uniform view of the purity and the universality of Islam. Mosque architecture discourse "directed" toward the homogenization of architectural expression refers to reply idioms nuances of Arabic as a tradition of Islamic origin. This is an interpretive effort to keep the purity of religious orthodoxy from filthy syncretic or heresy of local beliefs, and mosque architecture leads to the form of universal and essential. At first glance this effort is identical with the thinking of contemporary Modernism.

Second, the emergence of colonial constructs created by the Orientalists as a form of Western hegemony over the Islamic culture and civilization in the colonies ${ }^{4}$. The concept of homogeneity and was created as a representation of Islamic identity to facilitate supervision and "domestication" of Muslims colonized. As a result, the complexity and simplified Islamic entities into a single image. According to the Orientalists, a mosque can be said to have Islamic features if you have the form of minarets and domes. Therefore, understandable that in the old mosque in Java that does not have a tower, the Dutch authorities added that the minarets of its subordination to the efforts of Islamic culture. Because of the strength of Western hegemony and support the spirit of Pan-Islamism, this interpretation is spread very far into the perception of the colonial countries, thus the embodiment of wealth thriving mosque previously reduced to a mere form of the dome and minaret. Baiturrahman Great Mosque in Aceh designed by Dutch architect in the conquest of Muslim society efforts in Aceh. This conquest of the Islamic identity of uniformity so that the people of Aceh will be identified and “controlled" (Figure 7).

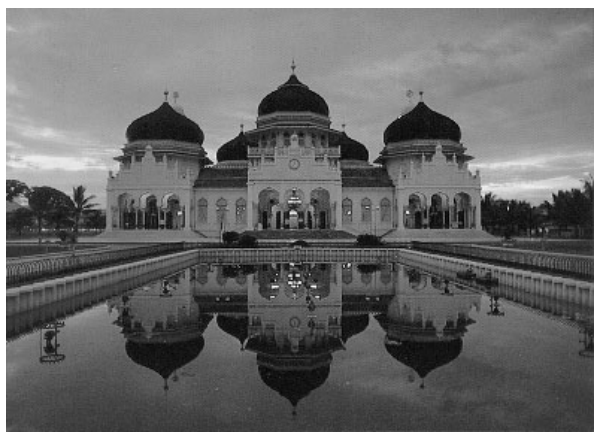

Figure 7. Baiturrahman Mosque in Banda Aceh. Power of Western hegemony and support the spirit of PanIslamism produce a reduced embodiment of the mosque into a dome or minaret. (Source: Indonesian Heritage, 2000) 
Architectural claim to show the existence of a muslim community as part of the world community seems to adoption of elements of Islamic smelling "International". Islamic identity "imagined" as a vague picture of a distant Arab countries. Architectural elements such as a bow shape, domes, and towers are supposed to represent "universal identity" of Islamic architecture. Revianto B. Santosa revealed that the dome or arch shape itself is problematic, to be labeled as Arabic ${ }^{5}$. In the Islamic world, these elements precisely in developing Turkey, Persia, and India. Arabic only receive the impact of these areas.

Unlike the region of Sumatra as Asian crosstrade in Malacca strait which have long mosque architecture under the influence "universal identity" Islam is a very intensive, a mosque on the island of Java in the early twentieth century also shows the presence of Pan-Islamic identity and resistance against . Masjid Al-Manar in Kudus as an example, presents the dome roof and forms a bow on the porch and at once the resistance do not to the elements of "universal Islam" is a major part of the building (Figure 8). Elements "outside" is just additional building attached to a pyramid-roofed mosque compound pre-existing. It's just that, combining the local and the newcamers elemets on the mosque was impressed as a patch that simplistic, naive, and without further processing.

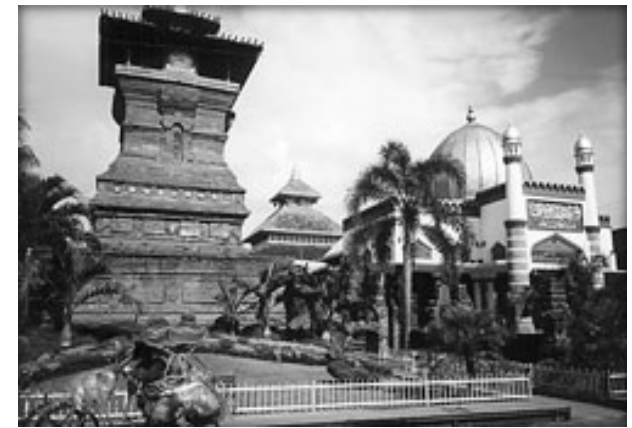

Figure 8. Al-Manar Mosque in Kudus. Section presents the porch roof of the mosque dome and the threshold arch (Source: Indonesian Heritage, 2000)

\section{Mosque Architecture Homogeneity II: The image of Modernism}

The condition of post-colonialism in Indonesia along with the proliferation of modern era as a time of necessity with some icons of rationality, technological and industrial progress. In this era of appears genre Modern architecture style mosque. Mosques are built with modern idiom and the principles of freedom of expression and form show ahistorical, out of local references. Mosque shows the influence of modernism who wants universal expression. This expression is achieved with the use of geometry to manipulate the elements and composition of the primary forms of abstract and contrast to create a variety of characters that manifests itself in the form of a work. Salman Mosque (in ITB) are examples of expressions of modernism, departing from the composition of geometric forms ahistorical, simplicity, reveal the material and structural integrity, without ornaments and decorations, and specifically shows the integration of lines (trunks), field (plate), or a lump (of clay) (Figure 9). The presence of this express cubikal geometric-mathematical beauty of a very rational.

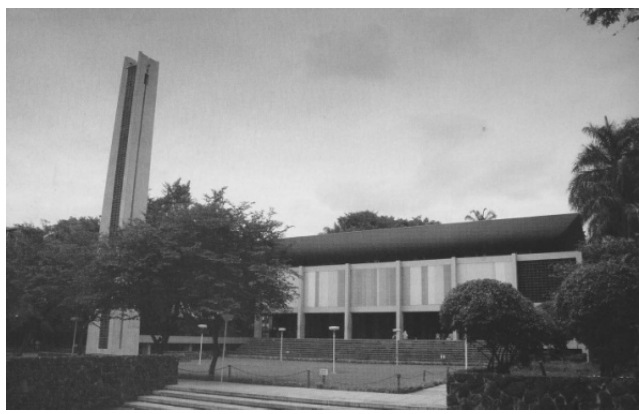

Figure 9. Salman Mosque in ITB, Bandung. Kubikal forms express geometric-mathematical beauty of a very rational. (Source: Indonesian Design, March 2006)

Homogeneity of the mosque architecture of this modern style can not be said to be a negative effort in vain that realized in the design. Homogeneity here is a logical consequence of applying the ideas of Modernism, such as avoiding reference styles of the past (historical style), back to the purity and rationality of the architecture of the "correct, logical, and clean of lies"6. Geometric elements in the mosque express "universal identity" Modern architecture.

\section{The Hybridity of Mosque Architecture}

The phenomenon of the development of mosque architecture in the contemporary era of shifting further towards the realization of architectural hybridity, as well as what happens in the design development "Demakan Mosque" in the past. Hybridity architecture look at a time when elements of the newcamers combined with elements of the local without the need to eliminate or ignore one of the elements. It should be stressed again that the architectural hybridity is the soul that gives character to the architecture of the mosque. Mosque architecture can not be determined essentiality of homogeneity or identity of the material. The Islamic concept underlying the design of mosques, with the nature and universality can instead embrace the diversity of architecture locality. If we only copy of past civilization forms of other nations (which is 
believed to be "universal identity" architecture of the mosque), then we effort a simplistic conditions and a mere imitation. Thus, the vision offered by the hybridity is an attempt to interpret our architectural wealth in an effort to face the future more complex.

Condition hybridity mosque architecture can be seen in the emergence of a dynamic tension between the use of "outside/international" forms and resistance "local" in the manifestation of the architecture with a variety of interpretations and synthesis efforts. Through a rich architectural exploration -both a transformation and a combination, these tensions can be overcome and a new equilibrium has to offer. Hybrid identities and then came through the encounter format of the local and the newcomers, the old and new, the normative and critical, all of which shown on the physical form of the architecture. Faced with questions about the identity of the increasingly prominent, the complexity and contradictions in the design of the mosque should be considered, not avoided. So combining style "Java" with "Arab" for instance, is a challenge. Ambiguity or plurality of identities is the potential to produce "a new hybrid architecture" that enrich the architecture. Below are discussed the potential of hybrid architecture design Syuhada Mosque, the Mosque of UGM campus, and (plan) Padang Great Mosque.

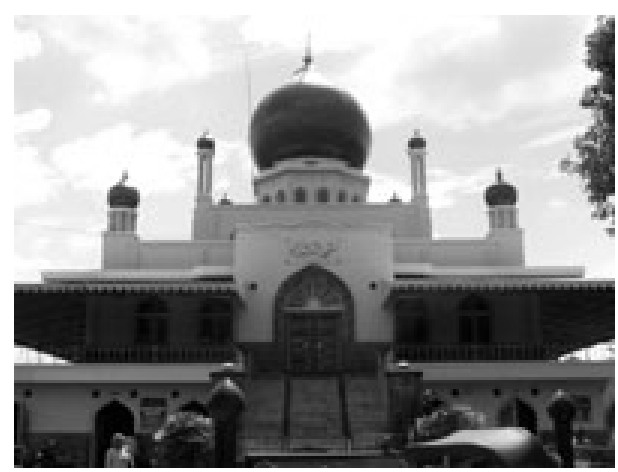

Figure 10. Syuhada Mosque in Jogjakarta. The design shows a synthesis between the local elements, PanIslamism and modern. (Source: Indonesian Heritage, 2000)

In design Syuhada mosque in Jogjakarta (Figure 10 above), visible local aspects, Pan-Islamism and modern obtain an interesting synthesis. The design of the building was built in the form of the figure that the smaller the compound above with a large dome at the top. It seems that the mosque was trying to close the local architectural expression, especially in the explicit appearance of the facade and roof forms. However, the overall composition of the mosque was very reminiscent of the ancient architectural traditions in the archipelago. Composition of the terraced square mass with a very conspicuous steps at the entrance is very similar to the displayed image building "punden berundak" in the pre-Islamic period, or in some ways similar Sukuh temple. Modernization of the mosque was seen in a number of transformation and integration among the elements, which rests on the creation of novelty of the appearance of cubical form that expresses geometric-mathematical beauty of a very rational.

In the design of the Mosque of UGM campus in Jogjakarta (Figure 11), looks interesting synthesis between the local aspects, the migrants, as well as the present. Local aspects seen through multilevel pyramid roof that takes a reference type "Demakan" (Javanese Vernacular). Aspects of the newcomers looked through the emphasis that invites the geometry Arabesk overlapping rectilinear pattern with 45 degrees of rotation into the formulation of "Islamic". This pattern applied to the plan of the roof top (brunjung) and "intercropping", even in the field of ornamentation patterns. Thus geometrically, the "Brunjung" is a merger of two pyramid roof with a rotation of 45 degrees. The present mosque is precisely because of the enrichment and development in many parts of the building as a result of the transformation and integration between contradictory elements: the local-the newcomers, old-new, tradition-modernity. Local elements in this mosque more ranking as "a subject that looked", because it still shows a strong local dominance both accommodative to the elements that were newcomers.

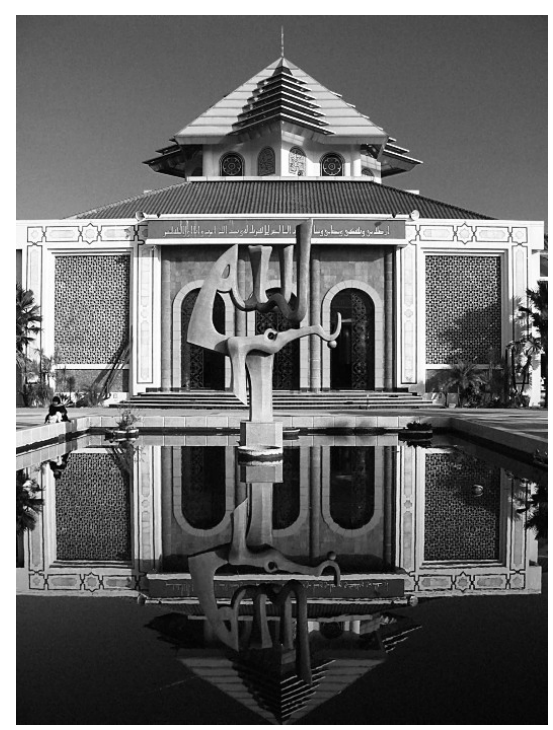

Figure 11. The Mosque of UGM campus in Jogjakarta. Islamis values articulated and brought into the context of Java, and traditions become a foothold into modernity. (Source: Majalah Hidayatullah, 2006)

Draft plan of Padang Great Mosque (Figure 12) has a charge of universal aspects of Islam as well as local aspects of Minangkabau. Universal physical aspects take inspiration story of hajar aswad pasting the Kaaba in the time of the Prophet. Once, when 
tribal leaders fight each other is a black stone placed on the Kaaba, the Prophet provides solutions to hajar aswad was taken by using a piece of cloth that should be caught up together. arch area formed by loading hajar aswad that is the inspiration of the roof of the mosque. As such, it describes the physical aspects symbol of wisdom and unity. Local aspects of Minangkabau indicated by the use of the archway "bagonjong" on the Minang ethnic house. Thus, physical appearance of the roof is a combination of universal aspects of Islam with the local aspects of Minangkabau. Both these aspects can be positioned as the two subjects of mutual dialogue in a parallel position.

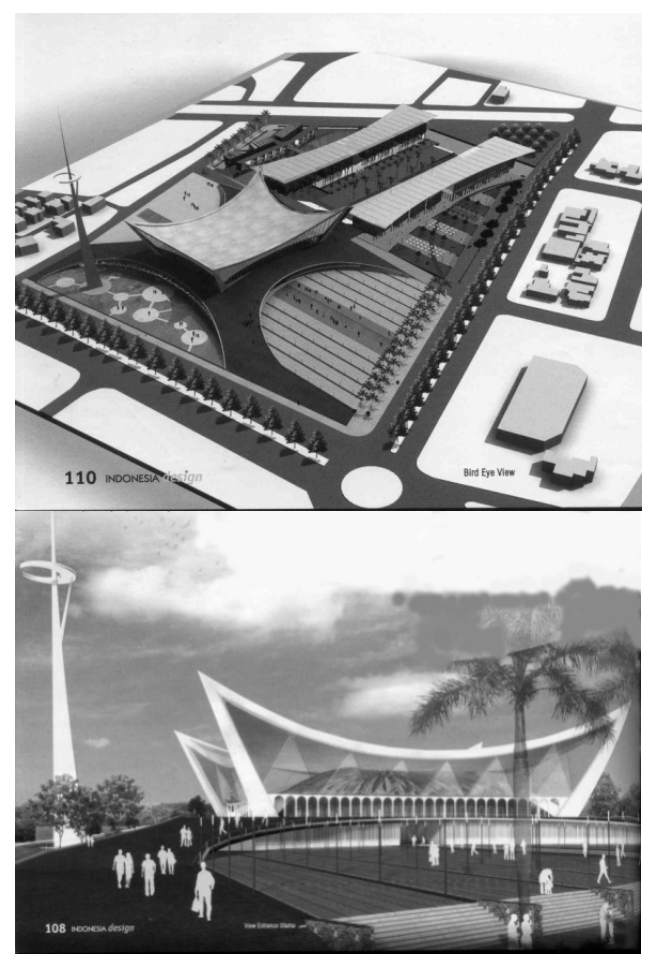

Figure 12. Draft Plan of Padang Great Mosque in West Sumatra. This object has a charge of universal aspects of Islam as well as local aspects of Minangkabau.

(Source: Indonesian Design Magazine, 2006)

The three examples of architecture in the same form of hybridity present dualism elements, contradictory, complementary, but present in a controlled fullness. On the one hand there are architectural elements that displays a number of orthodoxy, such as Qiblah direction orientation, articulation limiting element mosque, rows and delivery settings icons arabesk or calligraphy in a number of architectural elements. On the other hand, also shows the search for new and original solutions for a new manifestation of meaning in the context of the present: the transformation and combination. The Mosque of UGM Campus and the plan of Padang Great Mosque clearly demonstrate how Islamic values of articulated and brought into context to Nusantara, a tradition made ground towards modernity, and brought to normativitas of criticism without losing the substance of one of them. In other words, change the concept of homogenization into hybridity.

\section{Conclusion}

There are two point of departure in the design of mosque architecture in Nusantara, namely architectural homogeneity and architectural hybridity. Each provides the legitimacy of the architecture of identity formation. Architectural hybridity advantage lies in the ability to bring together "in dialogue" elements which contradicted each other without having to be one of the between and develop into a rich new form. In pursuit of the identity of the hybrids, this architecture utilizing elements of local architecture, traditions, or normative elements to accommodate the newcomers, modern, or critical element; but at the same time doing a critique of both and enrichment to his identity in the process of hybridity.

At this time, hybridity must be placed precisely in the context of looking forward. Currently Muslim communities confronted with conditions of modernity, in which we are faced with many choices that we carry from the past with new possibilities in the future. With the principle of universality is based on Islamic values and hybridity aspects with locality, the search expression and forms of architecture should reflect the efforts or our diligence in interpreting the condition of our modernity.

What should we consider in designing the architecture of worship, especially the mosque is how to build integration between aspects of the universality of Islam with aspects of Archipelago's locality. In designing mosque that expresses hybridity, an architect needs to take the right decisions and be wise ${ }^{7}$. In Indonesia, the design of mosques has developed a local conservation efforts (Nusantara), eventhough limited to the completion of the physical form. This effort is a good first step, given the sensory form of architecture is the entrance to the exploration of hybridity is a more in-depth architecture. Josef Prijotomo said, the ability of archipelago to participate in the architectural presence is now believed to be far more successful if preceded by appreciating the charm of architectural form ${ }^{8}$.

\section{References}

1 Hasan ud-Din Khan. 1994. "An Overview of Contemporary Mosques". In Martin Frishman \& Hasan ud-Din Khan (eds.) Mosque: History, Architectural Development and Regional Diversity. London: Thames \& Hudson 
2 Muhammad Muslih. 2008. Filsafat Ilmu. Jogjakarta: Belukar

3 Abdurrahman Wahid. 2001. Pergulatan Negara Agama, dan Kebudayaan. Jakarta: Desantara

4 Edward W. Said. 1995. Kebudayaan dan Kekuasaan: Membongkar Mitos Hegemoni Barat (terjemahan). Bandung: Mizan

5 Revianto B. Santosa. 1999. "Atap (Masjid Sunan Ampel) Dalam Dinamika Arsitektur Masjid Kontemporer Nusantara" in Proceeding of SNEIDAN 2: Atap Arsitektur Masjid. Surabaya: LSAI
6 Pudji P. Wismantara. 2010. “Arsitektur untuk Kemanusiaan: Humanisme Liberal Pont vis a vis Humanisme Pemerdekaan Mangunwijaya" in Proceeding Seminar Nasional Riset Arsitektur dan Perencanaan 1: Humanisme, Arsitektur dan Perencanaan. Jogjakarta: Architecture UGM

7 Galih Widjil Pangarsa. 2010. Materialisme pada Masjid Nusantara. Malang: You Publish. Arsiteknusantara.blogspot.com. 20 February 2010

8 Josef Prijotomo. 2009. "Sinopsis" in Rekontekstualisasi Arsitektur Nusantara. arsiteknusantara.blogspot.com. 19 December 2009 